\title{
Oxidant/Antioxidant Balance in Cows and Sheep in Antenatal Pathology
}

\author{
P. Sklyarov ${ }^{1}$, S. Fedorenko ${ }^{2}$, S. Naumenko ${ }^{2}$, P. Antonenko ${ }^{1}$, V. Zazharskyi ${ }^{1}$, \\ R. Mylostyvyi ${ }^{1}$, N. Zazharska ${ }^{*}$
}

${ }^{1}$ Dnipro State Agrarian and Economic University, Dnipro, Ukraine

${ }^{2}$ Kharkiv State Zoo Veterinary Academy, Kharkiv, Ukraine

Corresponding author E-mail: zazharskayan@gmail.com

Received: 10.09.2020. Accepted: 10.10.2020

\begin{abstract}
It has been established that antenatal pathology causes changes in the oxidant/antioxidant balance indices of cows within the range from $24.3 \%$ to $41.5 \%$, and in sheep - 17.2-26.2\%. In particular, in cows the content of serum catalase decreased by $29.9 \%$ and that of superoxide dismutase - by $29.1 \%$, in erythrocytes, catalase - by $35.7 \%$, and reduced glutathione - by $28.0 \%$, and by hemoglobin by $24.3 \%$, the number of red blood cells - by $28.7 \%$ and the concentration of 2,3 -diphosphoglycerate - by $41.5 \%$. At the same time, the content of malondialdehyde in serum and erythrocytes, on the contrary, increased by $32.4 \%$ and $32.5 \%$, respectively, and there was a change in oxidant/antioxidant balance from $1: 1$ to $1: 3$ conventional units. In sheep, the content of serum catalase decreased by $17.2 \%$ and that of superoxide dismutase - by $21.6 \%$, in erythrocytes catalase - by $23.9 \%$ and in reduced glutathione - by $21.1 \%$, hemoglobin content decreased by $26.2 \%$, the number of erythrocytes - by $24,1 \%$ and the concentration of 2,3-diphosphoglycerate - by $21.2 \%$. While the content of malondialdehyde in blood serum and in erythrocytes, on the contrary, increased by $23.7 \%$ and $22.3 \%$, respectively, and the change in oxidant/antioxidant balance occurred from $2: 1$ to $1: 3$ conventional units.
\end{abstract}

Keywords: Cows; Sheep; Antenatal pathology; Oxidant/Antioxidant balance

\section{Introduction}

The study is a fragment of the research projects in Ukraine: "Development and introduction of innovative methods and solutions using information technology devices in veterinary reproduction" and "Clinical correction of anthropogenic origin ecological destructions in domestic animals of Prydniprovsk industrial region". Antenatal pathology is the most common cause of perinatal losses, most of which have no direct obstetric causes and are related to the so-called inexplicable ones (Chavatte-Palmer et al., 2014, Silver, 1990, Tkachenko et al., 2016, Zazharska, 2016). Antenatal loss is characterized by a lack of generally accepted classification, a multitude of risk factors, imperfect diagnosis of causes, unresolved issues of pathogenesis and unclear tanatogenesis (Roescher et al., 2014, Mohebbi-Fani et al., 2013, Redline, 2008).

Due to the urgency and general needs of the veterinary medicine practice, antenatal pathology should be considered in a delimited, double variant, taking into account the parallel existence of the problems: 1) development and implementation of a system of diagnostic, treatment and preventive measures that ensure the normal course of pregnancy; 2) development and implementation of a system of diagnostic, treatment and preventive measures that provide optimal conditions for development and health of the embryo / fetus (Fotina et al., 2018, Zazharskyi et al., 2019b, Erişir et al., 2009, Gür et al., 2011).

Today, methods for diagnosing, treating and preventing antenatal pathology are usually complex, laborious or expensive, thus restricting their practical application. So the imperatives of today require to improve them.

One of the directions that will allow a more complete study of physiological and pathological aspects of antenatal development is the study of the oxidant/antioxidant balance, since the detection of damage caused by free radicals and protection of the body against it become more and more important in clinical medicine as an auxiliary tool for the metabolic status assessment.

In general, the question of the oxidants and antioxidants role in the pathology occurrence, including females of ruminants, is sufficiently studied (Gutyj et al., 2017, Lykkesfeldt \& Svendsen, 2007, Konvičná et al., 2015, Fassah et al., 2015, Zazharska et al., 2018, Zazharskyi et al., 2019a,c, Mutinati et al., 2013, Nawito et al., 2016).

Thus, Al-Qudah (2011) has studied the role of the oxidation stress and lipid peroxidation in the course of pregnancy and its complications in sheep with toxicosis of pregnancy. Mohebbi-Fani et al. (2013) indicate a decrease in the activity of superoxide dismutase and glutathione peroxidase during pregnancy and express an opinion on the role of oxidative stress in the development of pregnancy pathology. Merlo et al. (2008) note the potential role of oxidative stress as a trigger for the death of cells during luteolysis. After all, the yellow body is essential for the maintenance of pregnancy, but the excessive generation of free radicals causes damage to the membranes of the luteal cells, effects the production of progesterone and causes disorders of embryonic development. Erisir et al. (2009) believe that pregnancy is a condition that promotes oxidative stress. In their studies, the concentration of malondialdehyde in the blood plasma in the 2nd and the 3rd months of pregnancy in sheep was lower than in the 1st, 4th and 5th months of pregnancies and in non-pregnant sheep. The results of the studies indicate a decrease in the activity of catalase and the increased activity of the glutathione peroxidase after the 1st month. The glutathione peroxidase activity was the highest in the 2 nd and the 3rd months of pregnancy. The content of catalase was reduced after the 1 st month of pregnancy, and 
the lowest - in the 2nd and the 3rd months. Such changes in the studied indices may indicate a predisposition to the oxidative stress in the 2nd and the 3rd months of pregnancy in sheep.

However, some aspects, including the oxidant/antioxidant balance in the intrauterine development disorder, remain slightly clarified in general, remain poorly highlighted at all.

In this regard, the purpose of the research was to determine the oxidant/antioxidant balance in cows and sheep as a marker in software for diagnosis, therapy and prevention of antenatal pathology.

\section{Materials and Methods}

Experiments were carried out at the laboratories and clinical base of the Department of Veterinary Reproduction and Training and Production Center of Livestock and Crop Production at the Kharkiv State ZooVeterinary Academy, Department of Nanocrystalline Materials of the Institute of Scintillation Materials, National Academy of Sciences of Ukraine (Kharkiv).

The study objects were cows (breed - Ukrainian Black-and-White Milk, live weight 450-500 kg, age 5-8 years) and sheep (breed Precoce, live weight $40-45 \mathrm{~kg}$, age 3-5 years). In total, 40 livestock units (20 cows and sheep) were selected, which were divided into groups of analogues - 10 animals in each. The control animals were clinically healthy, those in the experimental group had antenatal pathology.

For the diagnosis of antenatal pathology (placental, embryo, fetopathy), commonly used methods of clinical, obstetric and gynecological studies were used, as well as special ones: colpocytoscopy and ultrasonography.

The content of malondialdehyde was determined by spectrophotometry, that of hemoglobin - by means of the hemoglobin-cyanide method, the number of erythrocytes- by counting in the Goryaev chamber (Levchenko, 2010), the reduced glutathione level spectrophotometrically according to the method of Gimerh (1967), catalase activity - by colorimetric method according to Korolyuk et al. (1988), activity of superoxide dismutase - by the method of Sirota (1999), concentration of 2,3-diphosphoglycerate - by spectrophotometry (Kee et al., 2010).

To determine the statistical reliability of the difference between the group mean, the parametric statistical method, Student's t-

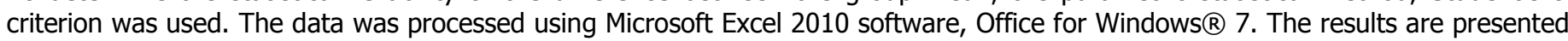
in the form of a mean $(M)$ and a sample mean $( \pm \mathrm{m})$ error.

\section{Results and Discussion}

The results of determining oxidant/antioxidant balance in cows and sheep in normal and in antenatal pathology are presented in Table 1.

Table 1. Oxidant/antioxidant balance in cows and sheep in norm and in antenatal pathology.

\section{Animal groups $(n=20)$}

\section{Indices}

\section{Pro-oxidant-oxidative system status}

Blood serum content:

- malondialdehyde, $\mu \mathrm{m} / \mathrm{l}$

-Catalase, $\mu \mathrm{m} / \mathrm{H}_{2} \mathrm{O}_{2} /$ l-min

- superoxide dismutase, $\mathrm{RU} / \mathrm{mgHb}$

Content in erythrocytes:

- malondialdehyde, $\mu \mathrm{m} / \mathrm{l}$

- Catalase, $\mu \mathrm{m} / \mathrm{H}_{2} \mathrm{O}_{2} / 1-\min$

- reduced glutathione, $\mu \mathrm{m} / \mathrm{I}$

- Prooxidant-oxidation ratio (RU)

Oxygen metabolism system status:

-Number of erythrocytes, T/L

-Hemoglobin content, $\mathrm{g} / \mathrm{l}$

-2,3- diphosphoglycerate concentration, $\mu \mathrm{mol} / \mathrm{l}$ cows $(n=20)$

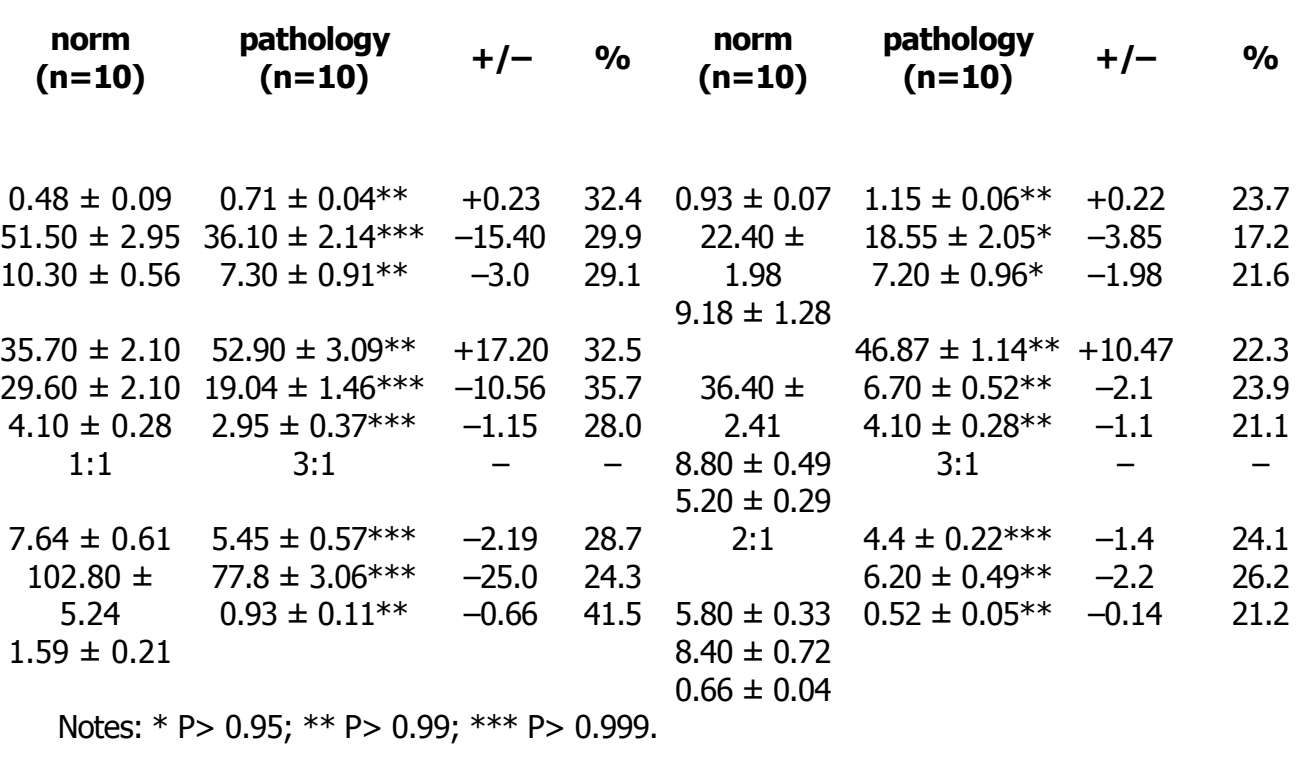

According to the obtained data, in cows with antenatal pathology, the content of catalase in blood serum decreased by $15.40 \mu \mathrm{M} / \mathrm{H}_{2} \mathrm{O}_{2} /$ I-min (29.9\%) and superoxide dismutase - by 3.0 conventional units / mgHb $(29.1 \%)$, catalase in erythrocytes - by $10.56 \mu \mathrm{M} / \mathrm{H} \mathrm{O}_{2} / \mathrm{I}-\mathrm{min}$ (35.7\%) and reduced glutathione - by $1.15 \mu \mathrm{M} / \mathrm{I}(28.0 \%)$, and also hemoglobin - by $25.0 \mathrm{~g} / \mathrm{I}(24.3 \%)$, the number of erythrocytes - by $2.19 \mathrm{~T} / \mathrm{L}(28.7 \%)$ 2,3- diphosphoglycerate concentration - by $0.66 \mathrm{mmol} / \mathrm{I}(41,5 \%)$. Meanwhile, malondialdehyde content in blood serum and erythrocytes, on the contrary, increased by $0.23 \mu \mathrm{M} / \mathrm{I}(32.4 \%)$ and $17.20 \mu \mathrm{M} / \mathrm{I}(32.5 \%)$, and the change in the prooxidantantioxidant ratio (pro-oxidant-oxidative system) from $1: 1$ to $1: 3$ conventional units.

A similar trend has been observed in sheep. In particular, the content of catalase in blood serum has decreased by $3.85 \mu \mathrm{M} / \mathrm{H} \mathrm{O}_{2} / \mathrm{I}-\mathrm{min}$ (17.2\%) and superoxide dismutase - by 1.98 conventional units / mgHb $(21.6 \%)$ and catalase in erythrocytes - by $2.1 \mu \mathrm{M} / \mathrm{H}_{2} \mathrm{O}_{2} / \mathrm{I}-\mathrm{min}$ (23.9\%) and reduced glutathione - by $1.1 \mu \mathrm{M} / \mathrm{I}(21.1 \%)$, and also, hemoglobin was by $2.2 \mathrm{~g} / \mathrm{I}(26.2 \%)$, the number of erythrocytes - by $1.4 \mathrm{~T} / \mathrm{L}(24.1 \%)$ and 2,3- diphosphoglycerate concentration - by $0.14 \mathrm{mmol} / \mathrm{I}(21.2 \%)$. Whereas malondialdehyde content in blood serum and in erythrocytes, on the contrary, increased by $0.22 \mu \mathrm{M} / \mathrm{I}(23.7 \%)$ and $10.47 \mu \mathrm{M} / \mathrm{I}(22.3 \%)$, respectively, and the change in oxidant/antioxidant balance was from 2:1 to $1: 3$ conventional units. 
Gür et al. (2011) found deterioration of oxidant/antioxidant balance due to the pregnancy stress in ewes in twin pregnancy compared to singlet pregnancy and non-pregnant animals. Mutinati et al. (2013) studied mechanisms of formation and influence of reactive oxygen species during physiological and pathological pregnancy, taking into account antioxidants and their significance in such a critical phase of the reproductive cycle in sheep. The authors found that reactive oxygen species are involved into fetal growth, since they promote replication, differentiation and maturation of cells and organs. However, an excess of reactive oxygen species can lead to changes in cells, harmful effects on the mother, the fetus and the course of pregnancy as a whole.

\section{Conclusion}

Thus, antenatal pathology causes changes in oxidant/antioxidant balance values of cows within the range from $24.3 \%$ to $41.5 \%$, and in sheep - $17.2-26.2 \%$. The study results will be taken as a basis for the development of diagnostic programs, due the need for the use of drugs and rehabilitation of reproductive function in antenatal pathology.

\section{References}

Al-Qudah, K. M. (2011). Oxidant and antioxidant profile of hyperketonemic ewes affected by pregnancy toxemia. Veterinary Clinical Pathology, $40(1), 60-65$.

Chavatte-Palmer, P., Lee, R., Bertolini, M., Jammes, H., Schmidt, M., \& Callesen, H. (2014). Pregnancy and Neonatal Care of SCNT Animals. Principles of Cloning, 107-126.

Erişir, M., Benzer, F., \& Kandemir, F. M. (2009). Changes in the Rate of Lipid Peroxidation in Plasma and Selected Blood Antioxidants before and during Pregnancy in Ewes. Acta Veterinaria Brno, 78(2), 237-242.

Fassah, D. M., Khotijah, L., Atabany, A., Mahyardiani, R. R., Puspadini, R., \& Putra, A. Y. (2015). Blood Malondialdehyde, Reproductive, and Lactation Performances of Ewes Fed High PUFA Rations Supplemented with Different Antioxidant Sources. Media Peternakan, 38(1), $48-56$.

Fotina, T. I., Fotina, H. A., Ladyka, V. I., Ladyka, L. M., Zazharska, N. M. (2018). Monitoring research of somatic cells count in goat milk in the eastern region of Ukraine. Journal of the Hellenic Veterinary Medical Society, 69(3), 1101-1108.

Gimerh, F. To the definition of blood glutathione. Laboratory science [K opredeleniju glutationa krovi. Laboratornoe delo], $1967 ; 564$.

Gür, S., Türk, G., Demirci, E., Yüce, A., Sönmez, M., Özer, Ş., \& Aksu, E. (2011). Effect of Pregnancy and Foetal Number on Diameter of Corpus Luteum, Maternal Progesterone Concentration and Oxidant/Antioxidant Balance in Ewes. Reproduction in Domestic Animals, 46(2), $289-295$.

Gutyj, B., Grymak, Y., Drach, M., Bilyk, O., Matsjuk, O., Magrelo, N., Zmiya, M., Katsaraba, O. (2017). The impact of endogenous intoxication on biochemical indicators of blood of cows with calves. Regulatory Mechanisms in Biosystems, 8(3), 438-443.

Kee, J., Paulanka, B., Polek, C. Handbook of fluid, electrolyte and acid base imbalance. 3rd ed. Delmar, 2010. 433.

Konvičná, J., Vargová, M., Paulíková, I., Kováč, G., \& Kostecká, Z. (2015). Oxidative stress and antioxidant status in dairy cows during prepartal and postpartal periods. Acta Veterinaria Brno, 84(2), 133-140. doi:10.2754/avb201584020133

Koroljuk, M., Levanova, A., Majorova, I., Tokarev, V. Method for determining catalase activity. Laboratory science [Metod opredelenija aktivnosti katalazy. Laboratornoe delo], 1988; 16-19.

Levchenko, V. Methods of laboratory clinical diagnosis of animal diseases [Metody laboratornoi' klinichnoi' diagnostyky hvorob tvaryn]. Kyiv: Agrarna osvita, 2010; 437.

Lykkesfeldt, J., \& Svendsen, O. (2007). Oxidants and antioxidants in disease: Oxidative stress in farm animals. The Veterinary Journal, 173(3), 502511.

Mohebbi-Fani, M., Mirzaei, A., \& Nazifi, S. (2013). Antioxidant vitamins and lipid peroxidation status in noncyclic versus cyclic ewes subjected to ram effect, before mating. Comparative Clinical Pathology, 23(5), 1551-1556.

Mutinati, M., Piccinno, M., Roncetti, M., Campanile, D., Rizzo, A., \& Sciorsci, R. (2013). Oxidative Stress During Pregnancy In The Sheep. Reproduction in Domestic Animals, 48(3), 353-357.

Nawito, M. F., Abd El Hameed, A. R., Sosa, A. S. A., \& Mahmoud, K. G. M. (2016). Impact of pregnancy and nutrition on oxidant/antioxidant balance in sheep and goats reared in South Sinai, Egypt. Veterinary World, 9(8), 801-805.

Redline, R. W. (2008). Placental Pathology: A Systematic Approach with Clinical Correlations. Placenta, 29, 86-91.

Roescher, A. M., Timmer, A., Erwich, J. J. H. M., \& Bos, A. F. (2014). Placental Pathology, Perinatal Death, Neonatal Outcome, and Neurological Development: A Systematic Review. PLoS ONE, 9(2), e89419.

Silver, M. (1990). Prenatal maturation, the timing of birth and how it may be regulated in domestic animals. Experimental Physiology, 75(3), 285307.

Sirota, T. (1999) A new approach to the study of the process of autooxidation of adrenaline and its use to measure the activity of superoxide dismutase. Questions of medical chemistry, 45(3), 263-271.

Tkachenko, A. A., Davydenko, P. O., Zazharskiy, V. V., \& Brygadyrenko, V. V. (2016). Biological properties of dissociative L- and other forms of Mycobacterium bovis. Visnyk of Dnipropetrovsk University. Biology, Ecology, 24(2), 338-346.

Zazharska, N. M. (2016). Bacterial contamination of milk at different temperatures and shelf life. Scientific Messenger of LNU of Veterinary Medicine and Biotechnology, 18(3(70)), 108-112.

Zazharska, N., Boyko, O., \& Brygadyrenko, V. (2018). Influence of diet on the productivity and characteristics of goat milk. Indian Journal of Animal Research, 52(5), 711-717.

Zazharskyi V., Davydenko P., Kulishenko O., Borovik I., Brygadyrenko V., Zazharska N. (2019a) Antibacterial activity of herbal infusions against Staphylococcus aureus, Staphylococcus epidermidis and Pseudomonas aeruginosa in vitro. Magyar állatorvosok lapja, 141(11), 693-704.

Zazharskyi V., Parchenko M., Fotina T., Davydenko P., Kulishenko O., Zazharskaya N. Borovik I. (2019b) Synthesis, structure, physicochemical properties and antibacterial activity of 1,2,4-triazoles-3-thiols and furan derivatives. Voprosy Khimii i Khimicheskoi Tekhnologii, (6), 74-82.

Zazharskyi, V. V., Davydenko, P. O., Kulishenko, O. M., Borovik, I. V., \& Brygadyrenko, V. V. (2019c). Antimicrobial activity of 50 plant extracts. Biosystems Diversity, 27(2), 163-169.

\section{Citation:}

Sklyarov, P., Fedorenko, S., Naumenko, S., Antonenko, P., Zazharskyi, V., Mylostyvyi, R., Zazharska, N. (2020). Oxidant/Antioxidant Balance in Cows and Sheep in Antenatal Pathology. Ukrainian Journal of Ecology, 10(5), 26-28. 